\title{
MEMAHAMI HEGEMONI MEDIA MASSA BARAT DAN STRATEGI PEMBERITAAN TERHADAP DUNIA ISLAM
}

\author{
Nurdin Nurdin \\ email: nnurdin@iainpalu.ac.id \\ Dosen Tetap Pada Jurusan Komunikasi dan Penyiaran Islam IAIN Palu
}

\section{Abstract:}

Western mass media is considered unfair and subjective in delivering news. Instead previous studies show that those western mass media have unfairly broadcasted news related Muslim people, limited studies have been carried out to show how those media broadcast the news and who control those media. This studi, therefore, tries to understand how western media broadcast news related Muslim people and who control those media. This studi employed content analysis in which the data was gathered from online sources and scholar journals. The findings show that western media use some strategies in broadcasting news such as making early claims during broadcasting, present false report and negative image, and use unproper language. The conclusion is that unfair news broadcasting related Muslim countries could be happened due to Jews domination in western mass media ownership and management. The limitation of this studi is that the data was merely gathered from online sources. Future research need to be carried out within broader context by involving journalists and communities.

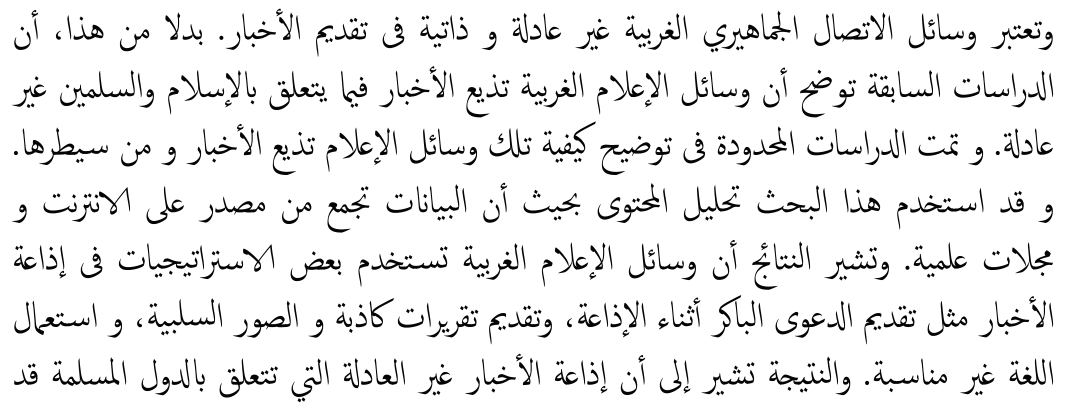


Nurdin Nurdin, Memahami Hegemoni Media Massa Barat...

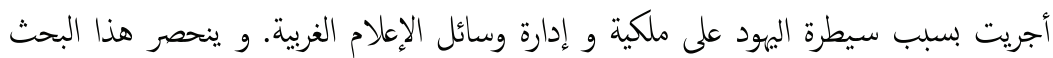

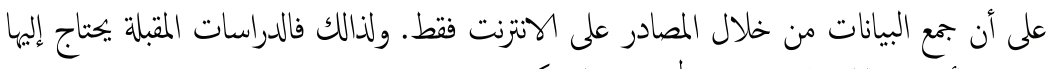

$$
\begin{aligned}
& \text { فى حالة أوسع بمطالبة الصحفيين والمجتمع في المشاركة فيها. }
\end{aligned}
$$

Kata Kunci: hegemoni, media barat, pemberitaan, dunia Islam

\section{Latar Belakang}

Media massa merupakan sarana yang sangat penting dalam peradaban masyarakat moderen terutama terkait dengan kebutuhan informasi publik. Media Massa dewasa ini semakin banyak dan beragam bentuknya. Dalam tulisan ini media massa di didefinisian sebagai saranama komunikasi yang melibatkan khalayak banyak ${ }^{1}$. Kebanyakan media massa menjadi saluran komunikasi yang bersifat one to many, dimana media massa tersebut menyampaikan informasi kepada banyak orang baik individu maupun kelompok. Saluran komunikasi tersebut menyampaikan informasi baik berupa berita, hiburan, pendidikan, data, atau pesan-pesan promosi dari berbagai perusahaan dan institusi.

Kebanyakan media massa besar dikuasai oleh perusahaan negara barat terutama Amerika Serikat, baik itu media cetak maupun media elektronik bahkan sampai Internet. Negara-negara berkembang umumnya mengambil berita dari perusahaan-perusahaan media barat tersebut. Misalnya CNN telah dimanfaatakan oleh banyak telivisi di dunia untuk dijadikan sumber berita, kemudian koran-koran besar seperti New York Times dan Washington Post juga dijadikan rujukan oleh banyak surat kabar di negara berkembang. Akibatnya, kebanyakan informasi yang disampaikan oleh media berbagai media massa di negara

${ }^{1}$ Sociology-Central. Defining The Mass Madia, (2011). Retrieved 08 Januari 2016, from Sociology Org, http://www.sociology.org.uk/media_defined.pdf. P.1 
berkembang seperti negara kita Indonesia bisa saja sangat dipengaruhi oleh perspektif penyedia berita pertama tersebut.

Meskipun hakekat dari media itu sendiri adalah netral dalam setiap penyajian informasi kepada publik, namun presentasi dan propaganda negatif media barat terhadap Islam bukanlah fenomena baru melainkan sudah sering terjadi ${ }^{2}$. Banyak strategi dan cara dilakukan dalam menyampaikan informasi yang dapat memojokkan Islam. Meskipun sudah ada sejumlah penelitian terkait maslah tersebut dan penelitian tersebut telah melaporkan tentang peran media barat dalam mendiskreditkan dunia islam, misalnya Ridouani ${ }^{3}$ dan Akhbarzadeh \& Smith $^{4}$, namum masih sedikit penelitian yang dapat menjelaskan bagaimana strategi media barat dalam menyajikan berita-berita yang mendiskreditkan dunia Islam.

Untuk itu, tulisan ini berusaha memberikan pemahaman tentang bagaimana startegi media massa barat dan media-media massa mana saja yang dianggap sering mendiskreditkan dunia Islam. Paper ini juga menyajikan sejumlah nama-nama pemilik media besar untuk meningkatkan pemahaman kita terhadap media massa barat dalam kaitannya dengan peran mereka dalam penyampain informasi kepada

${ }^{2}$ Alghamdi, E. A. The Representation of Islam in Western Media: The Coverage of Norway Terrorist Attacks. International Journal of Applied Linguistics \& English Literature, 4(3), 2015). 198-204. P. 203

${ }^{3}$ Ridouani, D. The Representation of Arabs and Muslims in Western Media. (RUTA, 3, 2011)., 15.

${ }^{4}$ Akbarzadeh, S., \& Smith, BThe Representation of Islam and Muslims in the Media: The Age and Herald Sun Newspapers, (Melbourne, .2005). 
Nurdin Nurdin, Memahami Hegemoni Media Massa Barat...

publik dunia. Untuk itu paper ini akan berusaha menjawab pertanyaan berikut ini:

Siapa saja pemilik media massa yang mendominasi pemberitaan dunia dan bagaimana mereka mengambarkan dunia Islam terutama terkait dengan penyajian berita yang mendisktreditkan Islam?

Sebagai pengingat, paper ini akan disajikan dengan urutan sebagai berikut; setelah bagian latarbelakang ini akan disajikan beberapa pengertian terkait dengan topik paper ini. Bagian ketiga akan dibahas pedekatan yang dilakukan dalam kajian ini. Selanjutnya pada bagian ke empat akan disajikan hasil dan pembahasan. Sementara kesimpulan dan penelitian selanjutnya akan dibahas pada bagian ke empat dan terakhir dari paper ini.

\section{Tinjauan Pustaka}

\section{a Pengertian Media Massa}

Kata media itu sendiri di artikan sebagai saluran komunikasi atau sarana dimana orang dapat mengirim dan menerima pesan ${ }^{5}$. Sedangkan media massa di definisikan sebagai berikut: "channels of communication that involve transmitting information in some way, shape or form to large numbers of people (although the question of exactly how many a "large number" has to be to qualify as a "mass" is something that's generally left undefined - it's one of those things that we know when we see it... $)^{6}$. Media massa dianggap memiliki kekuatan yang hebat dalam membentuk opini dan kepercayaan, merubah kebiasaan hidup, dan secara aktif membentuk perilaku dan memaksa penerimaan suatu pandangan politik

\footnotetext{
${ }^{5}$ Sociology-Central. (2011). Defining The Mass Madia, p.1

${ }^{6}$ Ibid, p.2
} 
tertentu ${ }^{7}$. Bahkan media massa dianggap memiliki kemampuan untuk merubah opini dan perilaku sipembaca ${ }^{8}$, misalnya media massa dapat merupah sikap konstituen dalam suatu kampanye politik9.

Media massa itu terbagi dalam dua bentuk yaitu media massa cetak dan media massa elektronik. Media massa cetak termasuk; surat kabar, majalah, tabloid, dll. Sedangkan media massa elektronik berupa televisi dan radio. Namun dengan perkembangan teknologi sekarang, media massa tidak hanya media tradisional seperti disebut diatas. tetapi media massa juga sudah termasuk internet dan media sosial online. Komunikasi massa jarak jauh sekarang sudah harus dilakukan dengan menggunakan jaringan Internet dengan cara menggabungkan dan fokus pada kontent tertentu untuk disampaikan kepada khalayak. Kontent online semacam ini dapat menjangkau jumlah audiens yang tak terhingga dan sering dimanfaatkan oleh para propaganda dan ahli hubungan masyarakat $^{10}$

Komunikasi massa jarak jauh sekarang sudah harus dilakukan dengan menggunakan jaringan Internet dengan cara menggabungkan dan

${ }^{7}$ McQuail, DThe Influence and Effect of Mass Media. In J.Curran, M. Gurevitch \& J.Woolacott (Eds.), Mass Communication and Society (pp. 70-93): (Sage Publications, Inc., 1979)

${ }^{8}$ Abroms, L. C., \& Maibach, E. W. The Effectiveness of Mass Communication to Change Public Behavior. Annual Review of Public Health, 29(1), 219-234. doi: doi:10.1146/annurev.publhealth.29.020907.090824, 2008.

${ }^{9}$ McCombs, M. E., \& Shaw, D. L. The Agenda-Setting Function of Mass Media. The Public Opinion Quarterly, 36(2), 1972), 176-187. P. 176

${ }^{10}$ Kandel, D. (2015). Mark Zuckerberg: An American Jewish tragedy. Retrieved 09 Januari 2016, from Digital News http://www.commdiginews.com/featured/markzuckerberg-an-american-jewish-tragedy-53783/ 
Nurdin Nurdin, Memahami Hegemoni Media Massa Barat...

fokus pada kontent tertentu untuk disampaikan kepada khalayak. Kontent online semacam ini dapat menjangkau jumlah audiens yang tak terhingga dan sering dimanfaatkan oleh para propaganda dan ahli hubungan masyarakat ${ }^{11}$. Karena itu ketika media massa konvensional saat ini sudah memanfaatkan teknologi internet untuk menigkatkan kemampuan meraka dalam menjangkau audien.

\section{b. Peran Utama Media Massa}

Secara alamiah media massa itu berperan sebagai information dessiminator atau penyebar informasi. Haque \& Hossain mengatakan bahwa peran mendasar dari media adalah untuk menginformasikan, mendidik, menghibur, dan membujuk orang. Media dapat merubah perilaku dan sikap seseorang dengan cara melakukan penekanan pemberitaaan pada isu-isu tertentu ${ }^{12}$. Namun dewasa ini media telah berubah menjadi arena perang kata-kata dan politik.

Internet sebagai media baru juga bersifat netral meskipun dibuat oleh orang Amerika. Kenetralan internet menjadi sangat penting untuk menjaga kebebasan berbicara dan berkomunikasi di komunitas internasiona $^{13}$. Dengan kenetralan media maka setia informasi yang

${ }^{11}$ Lang, K., \& Lang, G. E. Mass Society, Mass Culture, and Mass Communication: The Meaning of Mass. International Journal of Communication 3, 2009)., 998-1024. P.999

\begin{tabular}{|c|c|c|c|c|c|c|}
\hline Impact & $\begin{array}{l}{ }^{12} \mathrm{Haqu} \\
\text { on }\end{array}$ & $\begin{array}{l}\text { F., \& H } \\
\text { Conflict }\end{array}$ & $\begin{array}{l}\text { in, M. K. } \\
\text { Resolution }\end{array}$ & $\begin{array}{l}\text { 3). Global } \\
\text { Retrieved }\end{array}$ & $\begin{array}{r}\text { Media, } \\
08\end{array}$ & $\begin{array}{r}\text { Islamophobi } \\
\text { Januari }\end{array}$ \\
\hline
\end{tabular}

${ }^{13}$ Belli, L., \& Bergen, M. v. Protecting Human Rights through Network Neutrality: Furthering Internet Users' Interest, Modernising Human Rights and Safeguarding the Open Internet (2013), (pp. 54). Strasbourg: Steering Committee on Media and Information Society (CDMSI). 
disajikan terbebas dari kepentingan. Untuk itu para pelaku di dunia media seperti jurnalis perlu memahami tugas utama dari media massa. Tugas utama tersebut adalah memilih informasi yang relevan dan layak untuk diinformasikan kepada khalayak bukan hanya sekedar menyajikan ${ }^{14}$. Dengan kata lain jurnalis tidak hanya konsen dengan topik yang disajikan tapi juga dengan subjek yang ditujukan. Hal ini penting dilakukan agar informasi yang disajikan memberikan manfaat kepada publik.

\section{c. Strategi dan Kekuatan Media Massa}

Media massa merupakan sarana yang sangat efektif untuk menguasai perilaku publik. Dengan kata lain media massa bisa dimanfaatkan untuk membentuk dan merubah opini dan perilaku publik melalui berbagai informasi yang disajikan. Dijk mengatakan, media massa bisa menjadi suatu kekuatan yang mampu menakuti orang-orang (pejabat, publik, dll) melalui berbagai berita, gambar, karikatur, dll15. Dengan demikian media massa bisa menjadi senjata bagi para jurnalis dan sponsor. Masalah bagaimana penggunaannya tergantung pada yang memilikinya.

Meskipun media massa punya kemampuan untuk mengekploitasi publik, tapi bentuk exploitasinya bukanlah dalam bentu fisik. Perlu dipahami bahwa kekuatan media massa sebenarnya bersifat simbolis dan pembujukan dalam arti media pada dasarnya berpotensi mengontrol

${ }^{14}$ Adam, S. Bringing the Mass Media in The Contribution of the Mass Media for Understanding Citizens' Attitudes towards the European Union (pp. 23), (Berlin: Freie Universitat. 2009). P.6

${ }^{15}$ Dijk, T. A. v. (2013). Power and the News Media. Retrieved 09 Januari 2016, from University of Amsterdam http://www.discourses.org/OldArticles/Power\%20and\%20the\%20news\%20media.pdf 
Nurdin Nurdin, Memahami Hegemoni Media Massa Barat...

pikiran pembaca atau pemirsa secara tidak langsung ${ }^{16}$. Selanjutnya media massa menjadi powerful juga karena mereka punya akses ke berbagai wacana publik dan komunikasi. Sejumalah aktor (jurnalis) bahkan menjadi sangat sukses karena kepintaran mereka mengelola dan mengolah wacana publik tersebut.

Kelebihan media massa lainnya adalah kemampuan mereka menjangkau jumlah audien yang sangat luas. Bahkan dengan kehadiran teknologi Internet saat ini, hampir tidak ada lagi batas-batas geografis yang menghalangi jangkauan mass media. Informasi sudah bisa disajikan dalam bentuk realtime dimana publik pada suatu negara dapat melihat dan mendengat suatu informasi pada waktu yang bersamaan dimana informasi tersebut dihasilkan.

\section{d. Dominasi Media Massa}

Sebagian orang sering menggunakan kata "exploitasi" (Exploitation) ketika membicarakan penguasaan media massa barat dalam pemberitaan, terutama pemberitaan yang subjektif terhadap Islam. Padahal yang mereka masksud bisa jadi "hegemoni”. Kata "exploitasi" (exploitation) berarti politik pemanfaatan yang secara sewenang-wenang atau terlalu berlebihan terhadap sesuatu subyek. Eksploitasi biasanya dikaitkan dengan kepentingan ekonomi semata-mata tanpa mempertimbangan rasa kepatuhan, keadilan, serta kompensasi kesejahteraan ${ }^{17}$. Sedangkan kata "hegemoni" pada awalnya merujuk pada dominasi (kepemimpinan) suatu negara-kota Yunani terhadap

${ }^{16}$ Ibid

17 Oxford-Dictionary. (2015). Exploitation. Retrieved 11 Januari 2016, from Oxford Dictionary http://www.oxforddictionaries.com/definition/english/exploitation 
negara-kota lain dan berkembang menjadi dominasi negara terhadap negara lain. Dalam hubungan internasional, hegemon (pemimpin) menentukan politik negara bawahannya melalui imperialisme budaya, misalnya bahasa (lingua franca penguasa) dan birokrasi (sosial, ekonomi, pendidikan, pemerintahan), untuk memformalkan dominasinya.

Dalam konteks media massa, kata "hegemoni" bisa diartikan sebagai bentuk dominasi media massa besar dalam pemberitaan dunia baik dalam bentuk peliputan, penyampain, dan distribusi berita keseluruh dunia. Media massa besar tersebut menjadi dominan karena berbagai aspek yang antara lain karena penguasaan modal, sumber daya manusia, teknologi, dan infrastruktur komunikasi. Dengan penguasaan tersebut maka mereka bisa membuat media massa kecil lain diberbagai belahan dunia untuk tergantung kepada mereka. Akibatnya media massa kecil akan dengan mudah di dikte oleh media massa besar tersebut. Kemudian berpengaruh kepada penyampaian informasi yang bisa saja mengikuti kebijakan dan pola yang dilakukan oleh media massa yang dominan tersebut.

\section{Pendekatan Tulisan}

Tulisan ini merupakan penelitian kepustakaan yang sumber datanya berasal dari sumber online dan sekunder lainnya. Sumber sekunder tersebut berupa hasil-hasil penelitian terdahulu dari sejumlah jurnal yang membahas berbagai isu terkait hegemoni media massa barat dan strategi pemberitaan mereka terkait dunia Islam. Penulis juga menggunakan berbagai sumber online yang diambil dari berbagai situs yang juga membahas tentang hegemoni media barat terutama penguasaan media massa oleh Yahudi. Penggunaan data dari sumber 
Nurdin Nurdin, Memahami Hegemoni Media Massa Barat...

online adalah hal yang lazin dilakukan dalam suatu penelitian ${ }^{18}$ dan salah satu keuntungan mengumpulkan secara online adalah memungkinkan peneliti mendapatkan data dalam jumlah yang banyak dari berbagai situs $^{19}$. Data yang diperoleh lalu dianalisis menggunakan pendekatan konten analisis ${ }^{20}$. Hasilnya disajikan menurut tema tertentu sesuai dengan yang diperoleh dari hasil analisis tersebut.

\section{Hasil dan Pembahasan}

\section{a. Dominasi dan Penguasaan Media Massa}

Seperti dijelaskan di bagian tinjauan pustaka bahwa hegemoni media massa berarti dominasi media besar di dunia terhadap media massa kecil. Hasil penelitian ini menunjukkan bahwa media massa barat mendominasi penguasaan dan pemberitaaan media massa internasional. Menurut situs Socioecohistory bahwa ada enam group perusahaan Yahudi terutama di Amerika Serikat menguasai sekitar 96\% media dunia $^{21}$. Fakta ini menunjukkan betapa besarnya penguasaan media

${ }^{18}$ Granello, D. H., \& Wheaton, J. E. (2004). Online Data Collection: Strategies for Research. Journal of Counseling \& Development, 82(4), 387-393. doi: 10.1002/j.15566678.2004.tb00325.x

${ }^{19}$ Lefever, S., Dal, M., \& Matthíasdóttir, Á. (2007). Online data collection in academic research: advantages and limitations. British Journal of Educational Technology, 38(4), 574-582. doi: 10.1111/j.1467-8535.2006.00638.x

${ }^{20}$ Elo, S., \& Kyngäs, H. (2008). The qualitative content analysis process. [Article]. Journal of Advanced Nursing, 62(1), 107-115. doi: 10.1111/j.1365-2648.2007.04569.x

21 Socioecohistory. (2015). Six Jewish Companies Control 96\% of the World Media. Retrieved 09 Januari 2016, from Socio-Economis History https://socioecohistory.wordpress.com/2013/04/15/six-jewish-companies-control-96-of-theworlds-media/ 
massa dunia oleh Amerika Serikat, terutama warga Amerika keturunan Yahudi. Sejumlah perusahaan media massa terkenal dikuasai oleh warga Amerika keturunan Yahudi antara lain:

\section{1). Televisi}

Beberapa perusahaan pertelevisian atau yang mengelola stasiun televisi yang dimiliki atau dikelola oleh keturunan Yahudi antara lain:

- Walt Disney merupakan perusahaan hiburan raksasa yang juga memiliki stasiun televise seperti ESPN dan Disney Channel. CEO dari perusahaan ini adalah Michael Eisner keturunan Yahudi.

- American Broadcasting Company atau disingkat $A B C$ teridir dari dua devisi yaitu $A B C$ entertainment dan $A B C$ News (pemberitaan). $\mathrm{CEO}$ dari $\mathrm{ABC}$ news adalah James Goldston yang juga merupakan keturunan Yahudi.

- Stasiun televisi lain juga di komandoi oleh keturunan Yahudi seperti HBO (Gerald M. Levin), CBS (Laurence Tisch), CNN satu grup dengan MTV dan Universal Studio dipimpin oleh Edgar Bronfman, dan NBC (Andrew Lack).

\section{2). Surat Kabar}

Beberapa surat kabar terkenal juga dipimpin oleh orang-orang keturunan Yahudi. Surat kabar tersebut antara lain:

- The New York Times dipimpin oleh Sulzberge (Yahudi)

- The Washingtong Post

- The Wall Street Journal

- Majalah; Time, News Week, News and World Report

Namun menurut beberapa pakar ada sebanyak 1035 koran dan majalah yang berkaliber internasional dikuasai oleh taipan-taipan Yahudi 
Nurdin Nurdin, Memahami Hegemoni Media Massa Barat...

diberbagai belahan dunia barat. Ini membuktikan betapa besarnya pengaruh Yahudi dalam berbagai media yang mereka kuasai.

\section{3) Media Sosial}

Media sosial merupakan salah satu sarana yang sangat populer dewasa ini. Media sosial memang dibuat sebagai sarana untuk dapat saling berbagi informasi dan konten sesama pemakai diberbagai belahan dunia tanpa dibatasi oleh batas-batas geografis. Dewasa ini ada banyak aplikasi media sosial yang sudah dibuat baik yang cakupannya internasional maupun yang cakupannya dalam wilayah negara tertentu sesuai dengan bahasa negara tersebut misalnya situs Weibo di Cina dan situs Saling Sapa.com di Indonesia. Namun di Indonesia ada puluhan situs medsos lain yang khusus dibuat untuk pengguna warga Indonesia.

a) Facebook (Pemilik; Mark Zuckerberg). Dia lahir pada $14 \mathrm{Mei}$ 1984 merupakan seorang programmer yang orang tuanya keturunan Yahudi. Terlepas dari keturunan Yahudi, pendiri Facebook tersebut lebih netral dalam memandang dunia Islam. Bahkan dalam beberapa kesempatan dia membela Islam seperti dalam kasus bom Paris dengan tidak menyalahkan umat Islam secara general. Bahkan oleh beberapa pendukung Yahudi dia malah lebih memihal Islam ketimbang membela kasus-kasus kekerasan terhadap anak-anak Yahudi di Palestina ${ }^{22}$.

b) Google (pendirinya Larry Page and Sergey Brin). Sergey Brin adalah imigran Rusia keturunan Yahudi, sedangkan Larry Page ibunya yang berketurunan Yahudi. Namun Sergey Brin sendiri

22 Kandel, D. (2015). Mark Zuckerberg: An American Jewish tragedy. Retrieved 09 Januari 2016, from Digital News http://www.commdiginews.com/featured/markzuckerberg-an-american-jewish-tragedy-53783/ 


\section{$\Delta L-n i s H \exists \vec{\Delta} H$,Vol. 11 No. 2, Juli-Desember 2015: 211-236}

mengakui bahwa jadi Yahudi hanyalah masalah etnis semata bukan persoalan agama karena dia mengaku tidak taat dangan agama Yahudi ${ }^{23}$. Meskipun demikian pendangan Yahudi bisa saja masuk dalam sejumlah kebijakan Google terutama oleh pekerjapekerja dibawahnya. Salah satu media sosial milik Google yang terkenal adalah Google+. Begitu juga pendiri situs media sosial lain juga dimiliki oleh orang Yahudi, misalnya Yahoo (Terry Semel), Wikipedia (James Wales and Larry Sanger), MySpace (Josh Berman, Brad Greenspan, Tom Anderson), Amazone, dan Oracle (Larry Ellison).

Menurut sumber lain malah mengatakan bahwa sebenarnya hanya tujuh orang Yahudi saja yang sangat berpengaruh mengontrol media massa seperti ABC, NBC, CBS, the Turner Broadcasting System, CNN, MTV, Universal Studios, MCA Records, Geffen Records, DGC Records, GRP Records, Rising Tide Records, Curb/Universal Records, dan Interscope Records ${ }^{24}{ }^{25}$. Dengan kata lain masyarakat dari dunia ketiga sebenarnya mendapat informasi dan hiburan yang sampir seratus persen di pasok oleh orang-orang Yahudi. Tentu saja hal ini bisa saja menyebabkan ketergantungan warga negara dan pemerintah tersebut terhadap berbagai media yang dikuasai oleh orang Yahudi.

${ }^{23}$ Levinson, M. L, Are Larry Page and Sergey Brin Jewish? . (2015). Retrieved 09 Januari 2016, from Quora https://www.quora.com/Are-Larry-Page-and-Sergey-Brin$\underline{\text { Jewish }}$

${ }^{24}$ Whitley, J. Seven Jewish Americans Control Most US Media, (2013). Retrieved 09 Januari 2016, from Rense http://www.rense.com/general44/seveniewishamericans.htm

25 Jew-Watch. Electronic News \& Entertainment Media, (2015). Retrieved 15 Januari 2016, from Jew Watch http://www.jewwatch.com/iew-controlledpresstvnetworks.html 
Nurdin Nurdin, Memahami Hegemoni Media Massa Barat...

\section{b. Dampak Penguasaan Media}

Dampak yang ditimbulkan oleh dominannya penguasaan media oleh negara-negara barat terutama warga keturunan Yahudi yaitu terjadinya pengaruh pada berbagai kebijakan dalam suatu pemerintahan. Beberapa dampak tersebut dapat dijelaskan antara lain sebagai berikut:

\section{1). Dampak terhadap keputusan politik}

Media massa barat menguasai sumber-sumber informasi dan juga berbagai infrastruktur teknologi informasi. Akibatnya mereka menjadi pemasok utama informasi keberbagai negara didunia terutama dunia ketiga yang teknologi informasinya masih tertinggal. Dampak selanjutnya dari dominasi penguasaan informasi adalah seringnya keputusan politik suatu negara dipengaruhi oleh informasi dari media massa tersebut terutama dinegara-negara Islam. Isu semacam ini sudah pernah diteliti oleh Said ${ }^{26}$ dimana negara-negara Islam atau yang manyoritas penduduknya Islam seperti di wilayah timur tengah dan Asia sering dipengaruhi oleh media barat dalam membuat keputusan politik mereka. Tentu saja hasilnya bisa saja malah merugikan warga negara tersebut sendiri.

\section{2). Kontrol Terhadap Pemerintah}

Kontrol media massa terhadap pemerintah disini tidak dipahami seperti kontrol suatu parlemen terhadap suatu pemerintahan, tetapi kontrol yang dimaksud disini adalah pengaruh media massa secara tidak langsung terhadap suatu pemerintah dalam membuat suatu kebijakan.

${ }^{26}$ Said, E. E., Covering Islam: How the Media and the Experts Determine How We See the Rest of teh World, 20 ed., (London Vintage Book, 2008).. 
Pengaruh ini disebabkan oleh ketergantungan suatu pemerintahan terhadap informasi dari media massa terutama media massa yang ada dinegara-negara barat. Dalam hal ini media massa memainkan perannya dalam kerangka yang lebih luas dalam aspek-aspek sosial, budaya, politik, ekonomi, dan struktur kekuasaan dalam suatu masyarakat ${ }^{27}$.

\section{3). Ketergantungan}

Masalah ketergantungan terhadap media massa barat sudah menjadi lazim dalam dunia media massa dinegara-negara berkembang. Hal ini disebabkan media massa barat menguasai berbagai faktor seperti sumberdaya manusia (jurnalis), infrastruktur teknologi informasi, disemninasi informasi dan penyimpanan informasi. Media massa besar tersebut diatas umumnya menjadi penyupali berbagai berita kepada berbagai media massa yang ada dinegara-negara di dunia ketiga seperti Indonesia. Sebagai contoh media televisi dan surat kabar Indonesia sering mengambil berita dari CNN, ABC, Washington Post, Times dan lain-lain. Akibatnya informasi yang disampaikan oleh media massa lokal bisa saja dipengaruhi oleh perspektif atau pandangan negara penyuplai berita atau informasi tersebut. Begitu juga berbagai pemberitaan terhadap Islam bisa saja menjadi tidak objektif dan berimbang. Selanjutnya juga berdampak terhadap budaya dan perilaku masyarakat karena media massa barat tersebut bisa jadi memainkan kontrol terhadap pikiran dan jiwa generasi muda karena membaca berita dari media tersebut.

${ }^{27}$ Dijk, T. A. v. Power and the News Media. (2013). P.9 
Nurdin Nurdin, Memahami Hegemoni Media Massa Barat...

\section{4). Bias dalam pemberitaan}

Dominasi media massa barat juga berpengaruh terhadap berbagai pemberitaan. Dalam hal ini terjadinya bias dalam pemberitaan karena dominannya berita dari media massa barat tersebut. Bias yang dimaksud disini bukan hanya dalam arti subjektif berdasarkan pandangan mereka tapi juga dari segi kuantitatif dimana jumlahnya yang tidak berimbang. Hasil penelitian menyebutkan bahwa tingkat liputan berita terhadap umat Muslim menjadi sangat rendah karena media dikuasai oleh orang Yahudi.

Sebagai contoh hasil sebuat penelitian yang dipublikasikan di surat kabar The Guardian memperlihatkan bahwa 37\% warga non muslim di Eropa dan Amerika mengatakan bahwa meraka sangat jarang mendapatkan berita-berita tentang Islam di media-media massa dinegeri mereka $^{28}$. Yang lebih parah lagi adalah $41 \%$ dari responden tersebut juga mengakui bahwa berita-berita yang disajikan dimedia massa mereka sangat dipengaruhi oleh pandangan subjektivitas mereka terhadap dunia Islam dan Arab.

Hasil penelitian yang dilakukan oleh Akbarzadeh \& Smith ${ }^{29}$ terhadap surat kabar Herald Sun dan The Age di Australia memperlihatkan 22 persen berita terkait Islam membicarakan terorisme bukan berita-berita positif. Sebuah laporan lain yang dikeluarkan oleh Pemerintah Kuwait dan berdasarkan sebuah survey dan wawancara dengan pakar media juga menyebutkan bahwa berita-berita tentang

\footnotetext{
${ }^{28}$ Guardian, Media has anti-Muslim Bias, Claims Report from The Guardian, (2005).

http://www.theguardian.com/media/2005/nov/14/pressandpublishing.raceintheuk.p.1
}

${ }^{29}$ Akbarzadeh, S., \& Smith, B. The Representation of Islam and Muslims, (2005), P.11 


\section{$\Delta$ L-nis $H \exists \bar{\Delta} H$, Vol. 11 No. 2, Juli-Desember 2015: 211-236}

Timur Tengah di televisi barat lebih banyak berisi berita tentang terorisme, anti-Amerika dan perang Iraq.

Dampak negatif yang terjadi adalah banyak media barat (terutama di USA dan Inggris) pada dasarnya menanam benih-benih prasangka dan ketidak-rasionalitas dan juga mendistorsi gambaran Islam dan Muslim yang sebenarnya di dipikiran orang dunia barat. Islam dianggap sebagai agama yang melahirkan terorist, kekerasan, dan ancaman global ${ }^{30}$.

\section{c Strategi Penyajian Berita}

Strategi penyajian berita dan informasi merupakan salah satu aspek nyata yang dapat dilihat bagaimana media massa barat memainkan peran mereka dalam pembentukan opini terhadap dunia Islam. Beberapa strategi yang lazin dilakukan disajikan sebagai berikut:

\section{1). Membuat prasangka awal.}

Hasil laporan sebuah jurnal yang ditulis oleh Aghamdi ${ }^{31}$ memberi contoh bagaimana sebuah opini awal dibentuk oleh mass media. Dalam kasus penyerangan di sebuah pulau di Norwegia, seorang reporter (Ingraham) membuat tuduhan awal sebagai berikut: "in the 'back of the book' segment tonight, two deadly terror attacks in Norway, in what appears to be the work, once again, of Muslim extremists'. Padahal saat itu sipenyerang (Anders Behring Breivik) belum tertangkap. Dalam hal ini ada peran jurnalis yang berusaha membuat prasangka awal sebelum pihak kepolisian melakukan investigasi. Cara jurnalis tersebut menyajikan

${ }^{30}$ Said, E. E., Covering Islam, (2008).

${ }^{31}$ Alghamdi, E. A., The Representation of Islam in Western Media, (2015). 
Nurdin Nurdin, Memahami Hegemoni Media Massa Barat...

berita akan dengan cepat membentuk opini negatif publik terhadap dunia Islam. Meskipun dihari-hari berikutnya ditemukan bahwa yang melakukan teror tersebut tenyata bukan seorang Muslim, namun prejudice terhadap umat Muslim sudah terlanjut membekas di pikiran si pembaca.

\section{2). False Report}

Hal yang paling sering dilakukan mass media barat terkait pemberitaan terkait dunia Islam adalah melakukan false report. False report yang dimaksud disini bisa berupa penyampaian berita yang tidak utuh atau penyampaian berita yang tidak sesui dengan kenyataan sebenarnya. Dalam kontek penyampaian berita tidak utuh maka berita tersebut adalah benar adanya namun tidak lengkap di sampaikan sehingga dapat menyebabkan salah pemahaman. Sementara dalam kontek penyampaian berita yang tidak sesuai dengan kenyataan adalah penyampaian berita yang tidak sesuai dengan fakta yang terjadi dilapangan. Salah satu contoh misalnya pada 1 Oktober 2011 stasiun berita NBC milik Amerika melaporkan bahwa "ada tiga serdadu AS" dan "sejumlah warga Afganistan" telah terbunuh dalam suatu serangan bom bunuh diri di Afganistan. Pemirsa atau publik tidak diberi tahu bahwa "sejumlah warga Afganistan" tersebut sebenarnya 11 manusia yang terdiri dari empat polisi, seorang penerjemah dan enam rakyat sipil ${ }^{32}$. Pemberitaan semacam ini berusaha meringankan persoalan dipihak Afganistan dan dianggap kurang penting.

${ }^{32}$ Kanj, J. Why US media is biased against Arabs and Muslims, (2012). Retrieved 16 Januari 2016 http://www.redressonline.com/2012/10/why-us-media-is-biased-againstarabs-and-muslims/ 


\section{$\Delta L-\cap i s h \exists \vec{d} H$, Vol. 11 No. 2, Juli-Desember 2015: 211-236}

\section{3). Penyebaran Sentimen dan sikap negative terhadap Islam}

Sejumlah media massa barat juga sering melakukan penyebaran sentimen dan sikap negatif terhadap Islam. Hal ini sering dilakukan dengan penggunaan kata-kata tertentu yang bernuansa kekerasan dalam pemberitaan. Misalnya penggunaan kata-kata "Islam extrimis, radikal, dan Jihad". Meskipun kata jihad dalam Islam tidak mesti bermakna kekerasan tapi media barat telah mengasosiasikan dengan kekerasan seperti "bom" "teror", dll. Seperti yang dikatakan oleh Ridouni ${ }^{33}$ yaitu; the concept "jihad" is not confined in violent acts and war as it is conceptualized and recognized in Western world, but it is open to different acts and performances that a Muslim can perform. Jihad, for example, can be applicably related to an individual "refraining from wrongdoing", to a "woman agonizing in child-birth", to a "man struggling and endeavouring to up-bring his family",

Penyebaran sentimen juga sering dilakukan dengan cara mengasoisaikan simbol-simbol yang biasa digunakan umat muslim dengan kekerasan, seperti jenggot, jilbab, dll. Akibatnya setiap saat masyarakat non Muslim melihat kaum Muslim yang berjenggot dan berjilbab mereka menjadi berprasangka negatif seperti prasangka teroris dan radikalisme.

\section{4). Penyajian Gambar}

Gambar-gambar terkait muslim baik pakaian maupun symbolsimbol agama sering disajikan dalam konteks yang salah di media massa barat. Penyajian tersebut sering dilakukan bukan dalam rangka

33 Ridouani, D. The Representation of Arabs and Muslims in Western Media, (2011), .p.3 
Nurdin Nurdin, Memahami Hegemoni Media Massa Barat...

mempromosikan hal-hal yang positif tentang islam, tapi sering dimanfaatkan untuk memancing komentar negatif. Sebagai contoh gambar 1 berikut ini.

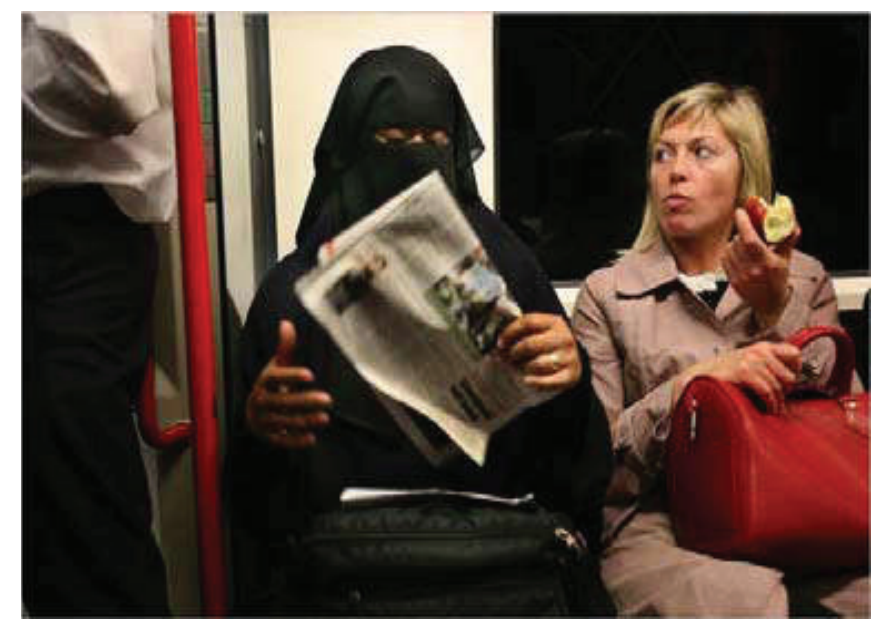

Sebenarnya tidak ada masalah dengan wanita muslim memakai cadar, namum karena wartawan menyajikan foto tersebut dengan seorang wanita lain yang menatap penuh curiga maka hal itu dapat menimbulkan prejudice dikalangan pembaca terutama pembaca dinegara non muslim yang belum tahu betul tentang pakaian Muslim.

Gambar 2 berikut ini juga memperlihatkan masalah yang sama, dimana seorang wanita Muslim yang menggunakan cadar sedang berjalan dan dilihat oleh warga lain dengan penuh curiga. 


\section{$\Delta L$-nis $H 3 \bar{\Delta} H$,Vol. 11 No. 2, Juli-Desember 2015: 211-236}

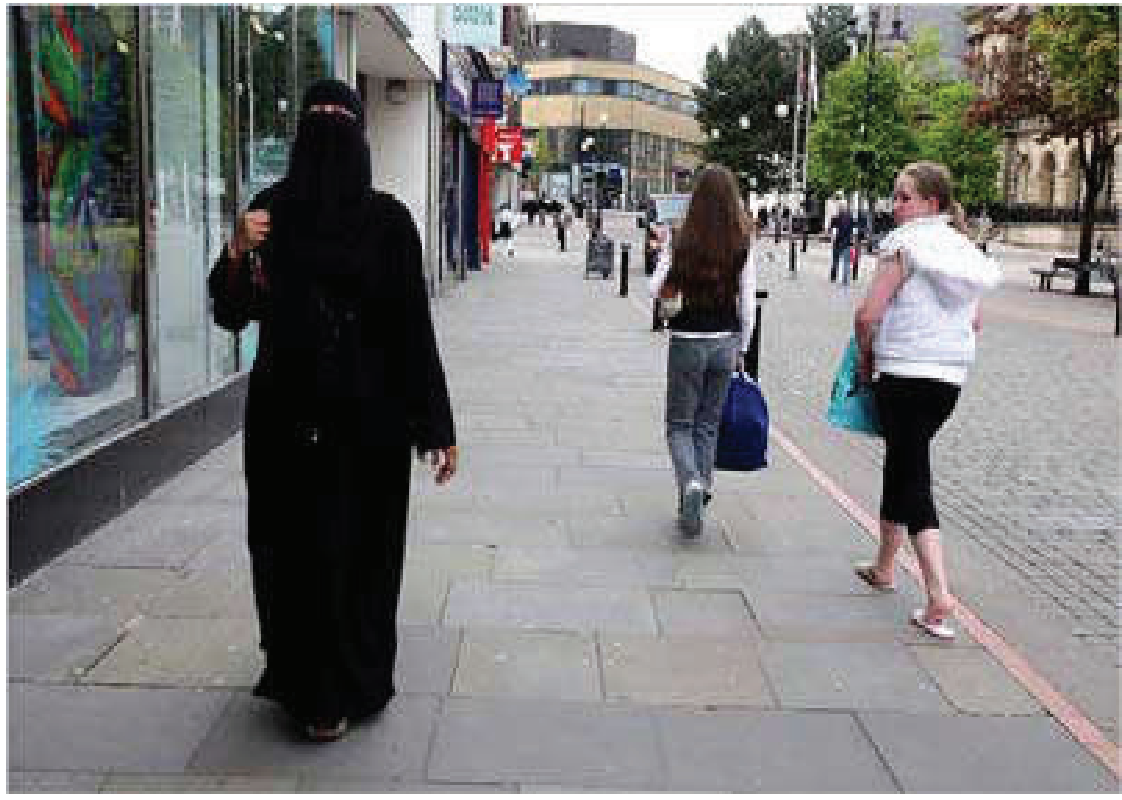

Seharusnya jurnalis atau media tidak perlu menyajikan gambar semacam itu. Jikapun sebuah media massa mau memperlihatkan suatu pakaian muslim yang unik maka mereka dapat saja menyajikan secara netral tanpa memperdampingkan dengan image lain yang dapat menimbulkan prejudice. Cara media barat menyajikan gambar tentang muslim semacam ini juga mempelihatkan bagaimana jurnalis atau media tersebut memang sudah memilki prejudice di pikiran mereka, yang kemudian berusaha di transferkan kepada publik. Dengan kata lain si jurnalis dan media tersebut berusaha membentuk opini publik kearah yang mereka inginkan.

Padahal publik yang belum membaca berita tersebut tidak memiliki pandang negatif terhadap Muslim. Namun dengan adanya penyajian-penyajian gambar semacam itu, maka secara perlahan-lahan publik juga akan memiliki pandangan yang sama dengan jurnalis atau 
Nurdin Nurdin, Memahami Hegemoni Media Massa Barat...

media tersebut. Dengan demikian media massa dapat menjadi sarana yang efektif untuk merubah perilaku masyarakat ${ }^{34}$. Kalau Baum \& Potter mengatakan bahwa media massa memainkan peranan yang krusial dalam mengumpulkan, membentuk dan mendistribusikan informasi sebagai salah satu komoditas pasar utama ${ }^{35}$. Karena itu media massa barat mampu dan berusaha memperlihatkan dunia Islam menurut keinginan mereka terutama dalam dua kerangka yaitu; dalam bentuk pertentangan dengan dunia barat dan pengasosiasian dengan terorisme dan extremist.

\section{5). Penggunaan bahasa}

Sejumlah media massa barat menggambarkan Muslim sebagai penyimpang sosial, tidak rasional, terbelakang, dan tidak berperadaban dan juga menjadi ancaman bagi dunia barat, melalui penggunaan bahasa dan kata-kata yang telah dimanipulasi ${ }^{36}$. Penggambaran semacam itu biasanya dilakukan melalui penggunaan bahasa dan istilah tertentu. Misalnya media barat menggunakan istilah "rerorisme" dan "ektermisme" ketika menggambarkan berbagai peristiwa yang terkait dengan Islam. Karena seringnya penggunaan istilah-istilah tersebut saat pemberitaan terkait Islam maka kata-kata "Muslim" dan "terorisme" dan "extrimisme" menjadi hampir sama dimata publik.

${ }^{34}$ Abroms, L. C., \& Maibach, E. W. The Effectiveness of Mass Communication, (2008), P.220

35 Baum, M. A., \& Potter, P. B. K., The Relationships Between Mass Media, Public Opinion, and Foreign Policy: Toward a Theoretical Synthesis. The Annual Review of Political Science, 11, (2008), 39-65. P.49

${ }^{36}$ Alghamdi, E. A. The Representation of Islam in Western Media, (2015), P.203 


\section{$\Delta L-\cap$ is $H \exists \bar{\Delta} H$,Vol. 11 No. 2, Juli-Desember 2015: 211-236}

\section{Kesimpulan}

Hasil penelitian ini menjunjukkan bahwa sejumlah besar media massa terkenal dikuasai atau dikelola oleh negara-negara maju di Amerika dan Eropa. Penguasa media massa tersebut kebanyakan keturunan Yahudi. Dampak dari dominasi media massa tersebut berpengaruh kepada berbagai kebijakan pemerintah terutama pemerintah di negaranegara dunia ketiga dan dunia Islam yang kebutuhan informasinya masih sangat teragantung pada dunia barat.

Media massa tersebut juga melakukan berbagai strategi penyampain berita yang menyebabkan terjadinya kesalahpahaman publik barat terhadap dunia Islam. Startegi tersebut antara lain prejudice dari jurnalis, false report, penyebaran sentimen, penyajian gambar-gambar yang menyudutkan Islam dan penggunaan bahasa yang mendiskreditikan Islam.

\section{Daftar Pustaka}

Abroms, L. C., \& Maibach, E. W. The Effectiveness of Mass Communication to Change Public Behavior. Annual Review of Public Health, 29(1), 219-234. doi: doi:10.1146/annurev.publhealth.29.020907.090824, 008.

Adam, S. Bringing the Mass Media in The Contribution of the Mass Media for Understanding Citizens' Attitudes towards the European Union (pp. 23). Berlin: Freie Universitat, 2009.

Akbarzadeh, S., \& Smith, B. The Representation of Islam and Muslims in the Media: The Age and Herald Sun Newspapers. Melbourne, 2005. 
Nurdin Nurdin, Memahami Hegemoni Media Massa Barat...

Alghamdi, E. A. The Representation of Islam in Western Media: The Coverage of Norway Terrorist Attacks. International Journal of Applied Linguistics \& English Literature, 4(3), 2015.

Baum, M. A., \& Potter, P. B. K. The Relationships Between Mass Media, Public Opinion, and Foreign Policy: Toward a Theoretical Synthesis. The Annual Review of Political Science, 11, 2008.

Belli, L., \& Bergen, M. v. Protecting Human Rights through Network Neutrality: Furthering Internet Users' Interest, Modernising Human Rights and Safeguarding the Open Internet (2013), (pp. 54). Strasbourg: Steering Committee on Media and Information Society (CDMSI).

Dijk, T. A. v. Power and the News Media. (2013). Retrieved 09 Januari 2016, from University of Amsterdam http://www.discourses.org/OldArticles/Power\%20and\%20the\%20n ews\%20media.pdf.

Elo, S., \& Kyngäs, H. The qualitative content analysis process. [Article]. Journal of Advanced Nursing, 62(1), (2008), 107-115. doi: 10.1111/j.1365-2648.2007.04569.x

Granello, D. H., \& Wheaton, J. E. Online Data Collection: Strategies for Research. Journal of Counseling \& Development, (2004). 82(4), 387-393. doi: 10.1002/j.1556-6678.2004.tb00325.x

Guardian. Media has anti-Muslim Bias, Claims Report from The Guardian (2005).

http://www.theguardian.com/media/2005/nov/14/pressandpublishi ng.raceintheuk

Haque, F., \& Hossain, M. K. Global Media, Islamophobia and Its Impact on Conflict Resolution (2013). Retrieved 08 Januari 2016 http://www.ihmsaw.org/resourcefiles/1260034024.pdf. 
Jew-Watch. Electronic News \& Entertainment Media. (2015). Retrieved 15 Januari 2016, from Jew Watch http://www.jewwatch.com/jewcontrolledpress-tvnetworks.html

Kandel, D. Mark Zuckerberg: An American Jewish tragedy. (2015). Retrieved 09 Januari 2016, from Digital News http://www.commdiginews.com/featured/mark-zuckerberg-anamerican-jewish-tragedy-53783/

Kanj, J. Why US media is biased against Arabs and Muslims. (2012). Retrieved 16 Januari 2016 http://www.redressonline.com/2012/10/why-us-media-is-biasedagainst-arabs-and-muslims/

Lang, K., \& Lang, G. E. Mass Society, Mass Culture, and Mass Communication: The Meaning of Mass. International Journal of Communication (2009). 3, 998-1024.

Lefever, S., Dal, M., \& Matthíasdóttir, Á. (2007). Online data collection in academic research: advantages and limitations. British Journal of Educational Technology, 38(4), 574-582. doi: 10.1111/j.14678535.2006.00638.x

Levinson, M. L. Are Larry Page and Sergey Brin Jewish? (2015). Retrieved 09 Januari 2016, from Quora https:/www.quora.com/Are-Larry-Page-and-Sergey-Brin-Jewish

McCombs, M. E., \& Shaw, D. L. The Agenda-Setting Function of Mass Media. The Public Opinion Quarterly, (1972). 36(2), 176-187.

McQuail, D. The Influence and Effect of Mass Media. In J.Curran, M. Gurevitch \& J.Woolacott (Eds.), Mass Communication and Society (pp. 70-93): Sage Publications, Inc. (1979). 
Nurdin Nurdin, Memahami Hegemoni Media Massa Barat...

Oxford-Dictionary. Exploitation. (2015). Retrieved 11 Januari 2016, from Oxford

Dictionary http://www.oxforddictionaries.com/definition/english/exploitation

Ridouani, D. The Representation of Arabs and Muslims in Western Media. RUTA 2011, 3, 15.

Said, E. E. Covering Islam: How the Media and the Experts Determine How We See the Rest of teh World (20 ed.). London Vintage Book, 2008.

SocioecohistorySix Jewish Companies Control 96\% of the World Media, 2015. Retrieved 09 Januari 2016, from Socio-Economis History https://socioecohistory.wordpress.com/2013/04/15/six-jewishcompanies-control-96-of-the-worlds-media/

Sociology-Central. Defining The Mass Madia, 2011. Retrieved 08 Januari 2016, from Sociology Org http://www.sociology.org.uk/media_defined.pdf

Whitley, J. Seven Jewish Americans Control Most US Media, 2013. Retrieved 09 Januari 2016, from Rense http://www.rense.com/general44/sevenjewishamericans.htm 